\title{
Testing out the disciplinary role of debt in Croatian banks
}

\author{
Mario Bambulović \\ Croatian National Bank, Zagreb, Croatia \\ mario.bambulovic@hnb.hr \\ Ivan Huljak \\ ivhuljak@gmail.com \\ Antonija Kožul \\ McKinsey \& Company, Zagreb, Croatia \\ antonijakozul@gmail.com
}

\begin{abstract}
According to the agency theory, debt brings discipline to management and therefore, one way of reducing agency costs is by increasing the level of indebtedness. Even though there are a number of specificities of banks as corporations, this agency theory postulate should still be valid. This research is motivated by the need to understand microeconomics of banking better, which could be especially rewarding in CEE countries where the issues of credit risk, bank capital and corporate governance are specific. Accordingly, by testing the disciplinary role of debt in Croatian banks, we contribute to the still scarce literature on bank governance in Croatia. We operationalise the research by first generating an efficiency measure, which we believe adequately represents management efforts and ability to maximize the value of owners' investment. In the next step, we explore the relation between banks' efficiency and leverage. Our results do not indicate that debt generally creates a discipline mechanism for bank managers in Croatia.
\end{abstract}

Keywords: Agency theory, banking sector, Croatia, managerial efficiency

JEL classification: E50, G21

DOI: 10.1515/crebss-2017-0004

Received: April 05, 2017

Accepted: June 26, 2017

Acknowledgments: This work has been partially supported by the Croatian Science Foundation under the project STRENGTHS no. IP-2013-9402.

Disclaimer: Views expressed in this article do not necessarily represent the views of Croatian National Bank or McKinsey \& Company. 


\section{Introduction}

The asymmetry of information between owners and management is perhaps more pronounced in the banking industry than in other sectors. Bank managers have access to far more information about the clients and the bank itself than bank owners do. At the same time, access to public safety nets makes the question of information asymmetry even more sensitive. Having that in mind, it should come as no surprise that banks are highly regulated with their capital levels monitored closely. Besides the "physics" behind the monitoring of optimal capital levels in terms of risk management, little attention is usually paid to the "chemistry" of the relationship between bank owners and the ones making the every-day decision on optimal levels of leverage in terms of maximising bank's profits.

The question of capital structure and agency costs in banking industry is also important from the perspective of the whole economy, as this industry provides credit to the real sector and therefore enhances economic growth. However, this issue is even more important in banking sectors of CEE countries where the pressure on bank capital is increased due to higher credit and market risks. In addition, banks in CEE countries are predominantly foreign owned with large international financial groups usually holding the majority of banking sector capital. Therefore, the determination of foreign owners to keep their investment in CEE banks is usually monitored with care, especially in crisis years.

Like most of the CEE banking sectors, foreign financial institutions that hold around $90 \%$ of banking sector assets predominately own Croatian banking sector. In addition, the banking sector is becoming more concentrated with the departure of smaller and usually domestically owned banks, mostly via mergers. The capital ratios in Croatian banking sector are high with total capital ratio amounting to $20.9 \%$ at end 2015. The major contributor to the increase in banks' capital adequacy after 2008 is the decrease of risk weighted assets, with the capital levels remaining high due to the relatively high retained earnings, while recapitalisations in form of inflow of fresh capital were generally absent from 2008 onwards.

Given the importance of bank capital and the potential of agency theory in helping to explain the relationship between managers and owners, the lack of research so far on agency theory in Croatian banking sector context, seems unjustified. In addition, with banks deleveraging towards their foreign owners in Croatia after 2008 it becomes interesting to question whether debt disciplines bank managers. We therefore contribute to the literature on Croatian banking sector and agency theory in banking by testing whether increased leverage disciplines managers as the agency theory would suggest, causing the reduction in agency costs.

After introduction and literature overview, we explain the rationale for using bank specific profit efficiency measure derived from Data Envelopment Analysis (DEA), which consists of cost and revenue efficiency. The advantage of this measure compared with financial ratios or indicators derived from stock market is that it can control for firm-specific factors outside the control of management that are not part of agency costs (Berger and di Patti, 2006). After this step, we explain data and methodology and proceed by testing the connection between bank leverage and profit / cost / revenue efficiency using a Panel Tobit regression. After presenting the results, we conclude and offer recommendation of further research.

All of the calculations are carried out in R programming language with the help of Benchmarking package developed by Bogetoft and Otto (2015). In the next step, regression analysis was carried out in Stata 13. 


\section{Literature overview}

One of the pillars of agency theory is financing structure dilemma. As Dobbin and Jung (2010) suggest, the agency cost associated with turning over management to non-owners stems from three propensities of management: a) to sacrifice profitability as to minimize the risk of firm failure, b) to over-reward themselves and drain profits and c) pursue short-term strategies that will benefit management rather than longterm strategies that will benefit shareholders. Accordingly, there are three strategies available in order to reduce agency costs: a) turning management into shareholders, b) forcing management to pay dividends, which will force them to issue new stock to open themselves up to additional shareholder monitoring and c) according to Jensen and Meckling (1976), take on debt. Debt should moderate the conflict of interests between shareholders and managers because managers would take on debt only when they are convinced that they can achieve rates of return that exceed cost of debt. Therefore, shareholders should prefer firm using debt as it shows that management is convinced that new projects will pay off. Shareholders would also prefer debt financing to new stock issuance as it could multiply their potential returns.

The relationship of capital structure and firm performance is often the subject of research. The foundations for this topic were laid down by Modigliani and Miler (1958), Modigliani and Miler (1963), Myres (1977), Jensen and Meckling (1976), Grossman and Hart (1982). Even though these papers managed to establish the relationship between leverage and performance, and popularize the agency topic in general, they were conducted from the perspective of non-financial companies. Even though banks and financial corporations in general are highly leveraged and strictly regulated, according to the agency theory, increasing leverage should provide discipline for their managers as well. Work of Berger and Bonaccorsi di Patti (2006) represents a significant empirical and methodological contribution to the literature of agency costs of debt in banking sector. Using a comprehensive methodology and custom-made indicator of bank profit efficiency, based on Distribution-free approach, authors show that agency costs are lower when bank leverage is increased. Similar methodology was applied on Australian deposit takers by Skopjak and Luo (2012) who concluded that on lower levels of leverage increasing leverage contributes to the higher profit efficiency of banks, however, consistent with the theory, on higher end of leverage distribution, increasing leverage increases the financial distress costs and outweighs the gains from increased managerial effort. Admati and Hellwig (2013) discuss the bank leverage from the long-term social welfare stance and conclude that leverage should be lower.

As Berger and Bonaccorsi di Patti (2006) mention, empirical evidence on the agency costs hypothesis in financial literature is inconclusive. Most of the tests rely on finding the relationship between firm performance and capital (or leverage) levels and other control variables. However, inability of researchers to create a universal measure of manager's effort often leads to the inconsistent results. A part of these inconsistencies comes from using a sub-optimal variable for measuring manager's effort: either ratios derived from financial statements (like simple return on assets) or stock market data (like stock market returns). Simple profitability ratios, like ROA as well as stock market returns cannot separate managerial effort from other exogenous factors. The goal of this research is also to help explain those inconstancies. 


\section{Measuring bank performance}

Our research goal requires a measure of managerial effort in running a bank. We do not use profitability ratios (like ROA, ROE) because we believe that they do not show managerial effort correctly, as they depend on many different factors that are not under managerial influence. The most important driver of bank profitability in crisis is credit risk (via impairment costs arising from the increased levels of non-performing loans). However, it is not obvious which part of the loan portfolio should be attributed to the current management decisions and which belongs in the legacy domain. In addition, those profitability measures are dependent of the economies of scale and the prices each bank faces which are not totally under control of the management.

Therefore, we believe that more appropriate indicator for our research is efficiency measure that will consider the prices the banks are facing as exogenous. Having this in mind, we are faced with the choice between two approaches of estimating banks' profit efficiency, more concretely between linear programming DEA method and parametric frontier analysis by means of SFA method. However, parametric frontier analysis is more data demanding which would lead to fewer observations in our case. We therefore, use Data envelopment analysis to derive bank specific profit efficiency measure that consists of cost and revenue efficiency.

Our bank-specific efficiency calculation is implemented in four steps. First, we calculate optimal (maximal) attainable revenue for each bank, based on the observed prices of banks' outputs and their selected combination of outputs. Secondly, based on the observed costs of inputs Croatian banks use in production process and their selected combination of outputs, we calculate optimal (minimal) attainable costs. Thirdly, given the evaluated optimal revenues and expenses, we calculate optimal attainable profit for every observed bank, which is used as benchmark and compared to observed banks' profits in the calculation of profit efficiency. Finally, we use the profit efficiency as a measure of banks' performance, where the appearance of inefficiency is to a certain extent attributed to the existence agency costs.

Optimal revenues are calculated using the DEA (Data Envelopment Analysis) method that employs techniques of linear programming in order to find the combination of outputs, which maximises banks' revenues while simultaneously assuring that the estimated combination of outputs can be attained, by the observed bank. Optimal costs are calculated using the same linear programming techniques by estimating the combination of inputs that minimises costs of banks' production process. This method is viewed as optimal due to its flexibility, which arises from the fact that as a nonparametric method it requires significantly less a priori model assumptions and does not request explicit mathematical form specification of the production function that is often a challenging proposition when banks are observed. Additionally, it is capable of handling multiple input, multiple output characterisations of production processes and enables quantification of inefficiency for every evaluated unit. Notable characteristic of DEA model is that it is deterministic and therefore it ignores the presence of random noise in data and it assumes that every variation in data carries some information about inefficiency of observed bank. This feature of DEA method should be taken into account when selecting input and outputs of production as any random variation in the data would be reflected in the efficiency measure. It should be also mentioned that DEA based efficiency measures are upward biased due to the fact that it estimates an empiric frontier composed of observed values of other banks and therefore it could be lower than theoretical frontier that is theoretically possible to attain. In multiple input multiple output environment, we estimate the technical frontier (best production 
practice) for every observed bank using the extreme point method which lies on the assumption that if one bank can produce a certain level of outputs from a certain level of inputs, then any other bank of similar size would also be able to do so. If we allow the creation of composite banks from existing ones (by including the convexity assumption), then we are able to construct the frontier for every possible combination of inputs and outputs. Efficiency measure will be estimated by comparing the observed input-output combination of each bank with its frontier solution.

As Table 1 shows, we observe bank as entity that transforms inputs (funds, labour and physical assets) into outputs (gross loans and investments) under the various circumstances using various money intermediation practices and different long-term "production" strategies. In other words, we view bank's business process as a "black box" where we can measure inputs, outputs and external factors while the very mechanics of production process remains unknown. In that context, we will define bank $b,(b=1, \ldots, K)$ as an ordered set of its inputs and outputs (Equation 1):

$$
\operatorname{Bank}^{\mathrm{b}}=\left(\mathrm{x}^{\mathrm{b}}, \mathrm{y}^{\mathrm{b}}\right), \mathrm{x}^{\mathrm{b}} \in \mathbb{R}_{+}^{3}, \mathrm{y}^{\mathrm{b}} \in \mathbb{R}_{+}^{2},
$$

where $K$ is a number of banks present in the market at observed time period (year).

Table 1 Variables used in calculation

\begin{tabular}{|c|c|c|}
\hline Variable & Name & Description \\
\hline Input 1 $\left(x_{1}\right)$ & Labour & Number of employees \\
Input 2 $\left(x_{2}\right)$ & Physical assets & Physical assets reported on bank's balance sheet \\
Input 3 $\left(x_{3}\right)$ & Funds (financing resources) & Deposits and short term credits \\
Output 1 $\left(y_{1}\right)$ & Gross loans & Loans before impairments and write-offs \\
Output 2 $\left(y_{2}\right)$ & Investments & Other assets (total ass. less gross loans and fixed ass.) \\
Cost 1 $\left(c_{1}\right)$ & Cost of labour & Wage per employee \\
Cost 2 $\left(c_{2}\right)$ & Amortisation & Amortisation of physical assets \\
Cost 3 $\left(c_{3}\right)$ & Interest expenses & Interest expense per unit of funds \\
Price 1 $\left(p_{1}\right)$ & Interest income & Interest income per unit of gross loans \\
Price 2 $\left(p_{2}\right)$ & Other non-interest income & Other non-interest income per unit of investments \\
\hline
\end{tabular}

Source: Authors' depiction.

Every DEA based analysis of efficiency and production possibilities is founded on the notion of production technology that gives us insight on how are inputs and outputs related, how we can substitute one input with another, or how level of outputs depends on level of inputs. The basic assumption of efficiency analysis is based on the notion that all banks share mutual technology that is defined by technology set (Equation 2):

$$
\mathrm{T}=\left\{(\mathrm{x}, \mathrm{y}) \in \mathbb{R}_{+}^{\mathrm{m}} \times \mathbb{R}_{+}^{\mathrm{n}} \mid \mathrm{x} \text { can produce } \mathrm{y},\right.
$$

where $m$ is number of inputs and $n$ is number of outputs used in production process. It can be seen from the definition of technology set that it contains the all of the observed values that banks realized in the observed period. In order to make relative comparison of banks with their theoretical frontier, technology set will be expanded by including two additional properties: free disposability of inputs and outputs and convexity. Free disposability property assumes that banks can discard unnecessary inputs as well as unwanted outputs for free. Convexity property assumes that if two different production technologies are accessible than every linear combination of those technologies is also accessible.

In order to make comparison of banks of different sizes, technology set has to satisfy returns to scale assumption that can be defined in general terms as $\gamma$-returns to scale shown in Equation 3:

$$
(\mathrm{x}, \mathrm{y}) \in \mathrm{T}, \kappa \in \Gamma(\gamma) \Rightarrow \kappa \cdot(\mathrm{x}, \mathrm{y}) \in \mathrm{T},,
$$


where $\Gamma(\gamma)$ is a set of possible scaling factors that depends on the choice of scaling possibilities. Our model will use the variable returns to scale (VRS) assumption where $\Gamma(\gamma)=\{1\}$. Therefore, the technology set will be defined as in Equation 4:

$$
\mathrm{T}=\left\{(\mathrm{x}, \mathrm{y}) \in \mathbb{R}_{+}^{\mathrm{m}} \times \mathbb{R}_{+}^{\mathrm{n}} \mid \mathrm{x} \geq \sum_{\mathrm{k}=1}^{\mathrm{K}} \lambda^{\mathrm{k}} \mathrm{x}^{\mathrm{k}}, \mathrm{y} \leq \sum_{\mathrm{k}=1}^{\mathrm{K}} \lambda^{\mathrm{k}} \mathrm{y}^{\mathrm{k}}, \sum_{\mathrm{k}=1}^{\mathrm{K}} \lambda^{\mathrm{k}}=1, \lambda^{\mathrm{k}} \geq 0, \mathrm{k}=1, \ldots, \mathrm{K}\right\} .
$$

First question that we need to address is to estimate how much revenue each bank would be able to generate if it was revenue efficient, given their observed inputs mix. To assess the possible improvement in terms of income generated by outputs, we need to include the price dimension into consideration. We assume that the prices of individual outputs in the given year are the same for all banks in the sample and are equal to observed income generated per unit of output on aggregate level. We can therefore for bank $b(b=1, \ldots, K)$ estimate the optimal revenue that is attainable within the technology $T$ in the year $t(t=1994, \ldots, 2015)$, by solving the following linear programming (LP) problem with $K+2$ variables (as depicted in Equations 5-8):

$$
\begin{gathered}
\max _{y_{1, t}, y_{2, t}, \lambda^{1}, \ldots, \lambda^{K}} r_{t}^{b}=p_{1, t} \cdot y_{1, t}+p_{2, t} \cdot \mathrm{y}_{2, \mathrm{t}}, \\
\text { s.t. } x_{i, t}^{b} \geq \sum_{k=1}^{K} \lambda^{k} x_{i, t}^{k}, \quad i=1,2,3 ; t=1994, \ldots, 2015, \\
y_{j, t} \leq \sum_{k=1}^{K} \lambda^{k} y_{j, t}^{k}, \quad j=1,2, t=1994, \ldots 2015, \\
\sum_{k=1}^{K} \lambda^{k}=1, \lambda^{k} \in \mathbb{R}_{+},
\end{gathered}
$$

where $p_{j, t},(j=1,2)$ is a price of output $y_{j}$ in the year $t, x_{i, t}^{k}$ is observed level of input $I$ of the bank $k$ in the year $t, y_{j, t}^{k}$ is observed level of output $j$ of the bank $k$ in the year $t$. In this linear problem, we maximise goal function, which measures optimal revenues attainable within the technology $\mathrm{T}$. It is ensured that the bank $b$ is able to produce revenue-optimal combination of outputs $\tilde{y}_{t}^{b}$ by requiring that $\left(x_{t}^{b}, \tilde{y}_{t}^{b}\right) \in T$ which is secured by conditioning that there is a convex combination of observed production plans that (weakly) dominates revenue-optimal production plan $\left(x_{t}^{b}, \tilde{y}_{t}^{b}\right)$ of bank $b$.

Possible improvements on the cost side for bank $b(\mathrm{~b}=1, \ldots, \mathrm{K})$ in the year $t(t=$ $1994, \ldots, 2015)$, are calculated in the same way, by solving LP problem that finds optimal cost-minimising input combination $\tilde{x}_{t}^{b}$ that is able to produce observed output mix $y_{t}^{b}$ (as depicted in Equations 9-12):

$$
\begin{gathered}
\min _{x_{1, t}, x_{2, t}, x_{3, t}, \lambda^{1}, \ldots, \lambda^{K}} c_{t}^{b}=c_{1, t} \cdot x_{1, t}+c_{2, t} \cdot x_{2, t}+c_{3, t} \cdot x_{3, t} \\
\text { s.t. } x_{i, t} \geq \sum_{k=1}^{K} \lambda^{k} x_{i, t}^{k}, \quad i=1,2,3, t=1994, \ldots 2015 \\
y_{j, t}^{b} \leq \sum_{k=1}^{K} \lambda^{k} y_{j, t}^{k}, \quad j=1,2, t=1994, \ldots, 2015 \\
\sum_{k=1}^{K} \lambda^{k}=1, \lambda \in \mathbb{R}_{+}^{K}
\end{gathered}
$$

where $c_{i, t},(i=1,2,3)$ is a price of output $x_{i, t}$ in the year $t, x_{i, t}^{k}$ is observed level of input $I$ of the bank $k$ in the year $t, y_{j, t}^{k}$ is observed level of output $j$ of the bank $k$ in the year $t$. By combining optimal levels of revenues $\tilde{r}_{t}^{b}$ and costs $\tilde{c}_{t}^{b}$ and comparing them to observed levels of revenues and costs, we can calculate the optimal profit (Equation 13) $\tilde{p}_{t}^{b}$ bank $b$ would be able to attain in the year $t$ if it was profit efficient as:

$$
\tilde{p}_{t}^{b}=\tilde{r}_{t}^{b}-\tilde{c}_{t}^{b}
$$

Furthermore, by comparing the observed profit $p_{t}^{b}$ with the optimal profit $\tilde{p}_{t}^{b}$ bank could have attained, we can create a measure of profit efficiency (Equation 14) of bank $b$ in year $t$ as:

$$
P E_{t}^{b}=\frac{p_{t}^{b}}{\tilde{p}_{t}^{b}}=\frac{r_{t}^{b}-c_{t}^{b}}{\tilde{r}_{t}^{b}-\tilde{c}_{t}^{b}}
$$

where $r_{t}^{b}$ denotes the revenues of the bank $\mathrm{b}$ in year $t$ and $c_{t}^{b}$ denotes the costs of the bank $b$ in year $t$. 


\section{Data and methodology}

Our initial sample for research is an unbalanced panel of 72 banks over 22 years (1994 - 2015) making 904 observations overall, which was after the exclusion of outlier observations reduced to 825 observations. Out of 72, 26 banks were present on the market at the end of 2015 , out of which 23 banks were present in the whole sample. The data is collected from statistical and supervisory reports gathered by the Croatian National Bank. The number of banks in the sample decreases over time, with the biggest reduction recorded at the beginning of the sample in late nineties when the banking crisis occurred. After 2002, the decrease in the number of banks is continuous but steady and was mostly the result of merger activities during the still ongoing process of market consolidation. Therefore, after 2002, the structure of the banking system and our sample remained relatively stable with concentration levels similar to today's levels and with foreign institutions owning around $90 \%$ of the banking sector total assets.

Having a comprehensive measure of bank profit efficiency allows us to test agency theory also by using its elements separately: revenue efficiency and cost efficiency. Finally, it should be mentioned that finding the statistically significant connection between leverage and bank efficiency is not enough to test the agency cost of debt, but that relationship should also be tested on different levels of leverage. As the agency theory suggests, increasing leverage should increase efficiency.

\section{Variables}

Our set of independent variables can be grouped into four categories (Table 2). Banks specific variables describe individual bank data that we believe can influence profit efficiency. Profit efficiency (PREFF) is our dependent variable calculated from DEA. Leverage (LEVER) shows the ratio of deposits and short-term loans to total assets and represents our main independent variable. According to agency theory, the estimated coefficient related to this variable should be positive, as greater leverage should discipline managers' to act more in sync with shareholders' expectations and therefore increase banks' profit efficiency. In addition, we expect that higher credit risk (CR_RISK) should motivate efficiency, as management might want to support profitability with efficiency gains to protect the capital burdened with loan losses. Finally, we include bank size (LN_SIZE) measured as natural logarithm of assets, as we expect larger banks to be more profit efficient as they can benefit from economies of scale but also have more resources available to form a superior business strategy.

Structural and macro variables represent exogenous variables influencing profit efficiency. Herfinhal-Hirschman index (HHI) measures the concentration level of a certain market with sum of squared market shares for each company. We expect $\mathrm{HHI}$ to negatively influence bank profit efficiency as higher concentration decreases the competition and reduces the need of managers to extract maximum effort. Although it would be possible to calculate market power measures, it should be noted that the majority of market power measures (like Lerner index) include profitability, which could cause endogeneity problem. GAP represents the difference between actual and potential economic growth. We expect negative relationship between GAP and cost efficiency and positive between GAP and revenue efficiency. However, at this point we do not know how this will influence profit efficiency. 
Table 2 Variables used in the model estimation

\begin{tabular}{|c|c|c|c|c|c|c|}
\hline Symbol & Definition & Exp. sign & Mean & Std. Dev. & Min & Max \\
\hline \multicolumn{7}{|c|}{ Dependent variable } \\
\hline PREFF & $\begin{array}{l}\text { Profit efficiency (closeness of a bank to the most } \\
\text { profit efficient bank on the market) (rel.) }\end{array}$ & & 0.41 & 0.36 & -0.92 & 1.00 \\
\hline REFF & $\begin{array}{l}\text { Revenue efficiency (closeness of a bank to the } \\
\text { most revenue efficient bank on the market) (rel.) }\end{array}$ & & 0.71 & 0.19 & 0.14 & 1.00 \\
\hline CEFF & $\begin{array}{l}\text { Cost efficiency (closeness of a bank to the most } \\
\text { cost efficient bank on the market) (rel.) }\end{array}$ & & 0.74 & 0.20 & 0.19 & 1.00 \\
\hline \multicolumn{7}{|c|}{ Inputs for calculating PREFF, CEFF, REFF } \\
\hline EMPL & $\begin{array}{l}\text { Labour input calculated as: number of employees } \\
\text { (abs.) }\end{array}$ & & 465.69 & 884.33 & 5.00 & 4715.00 \\
\hline FUNDS & $\begin{array}{l}\text { Funds input calculated as: deposits and short-term } \\
\text { loans (In abs.) }\end{array}$ & & 13.53 & 1.93 & 7.17 & 18.19 \\
\hline PHY_AS & $\begin{array}{l}\text { Physical assets input calculated as: assets with } \\
\text { physical dimension (In abs.) }\end{array}$ & & 10.14 & 1.71 & 1.79 & 14.04 \\
\hline PR_FUN & $\begin{array}{l}\text { Price of funds calculated as: interest costs / } \\
\text { (deposits + short-term loans) (rel.) }\end{array}$ & & 0.06 & 0.24 & 0.00 & 7.23 \\
\hline$P R \_L A B$ & $\begin{array}{l}\text { Price of labour calculated as: cost of labour / } \\
\text { number of employees (rel.) }\end{array}$ & & 131.93 & 68.41 & 0.00 & 1191.26 \\
\hline PR_PHY & $\begin{array}{l}\text { Price of physical assets: depreciation / physical } \\
\text { assets (rel.) }\end{array}$ & & 0.24 & 0.52 & 0.00 & 9.06 \\
\hline LOANS & $\begin{array}{l}\text { Total granted loans calculated as: gross loans (net } \\
\text { loans + loan loss reserves) (In abs.) }\end{array}$ & & 13.43 & 1.87 & 5.46 & 18.17 \\
\hline INV & $\begin{array}{l}\text { Investments calculated as: all bank assets besides } \\
\text { physical assets and loans (In abs) }\end{array}$ & & 12.85 & 1.95 & 6.34 & 17.40 \\
\hline \multicolumn{7}{|c|}{ Explanatory variables in efficiency model } \\
\hline \multicolumn{7}{|c|}{ Bank specific variables } \\
\hline LEVER & $\begin{array}{l}\text { Leverage indicator calculated as: (total deposits } \\
\text { and total short-term loans) / total assets (rel.) }\end{array}$ & + & 0.80 & 0.17 & 0.00 & 1.01 \\
\hline LEVER_SQ & Square of LEVER & $+/-$ & 0.34 & 0.10 & 0.00 & 0.51 \\
\hline CR_RISK & $\begin{array}{l}\text { Credit risk (total value adjustments to total assets) } \\
\text { (rel.) }\end{array}$ & + & 0.02 & 0.04 & -0.12 & 0.59 \\
\hline LN_SIZE & Natural logarithm of bank assets (In abs.) & + & 13.83 & 1.85 & 8.79 & 18.49 \\
\hline \multicolumn{7}{|c|}{ Structural and macro variables } \\
\hline $\mathrm{HHI}$ & $\begin{array}{l}\text { Herfindahl-Hirschman index of bank assets } \\
\text { concentration calculated as sum of squared } \\
\text { market shares in each year (abs.) }\end{array}$ & - & 0.13 & 0.02 & 0.00 & 0.16 \\
\hline DUM_1998 & $\begin{array}{l}\text { Dummy variable indicating the year } 1998 \text { when } \\
\text { banking sector recorded significant losses as a } \\
\text { result of banking crisis (bin.) }\end{array}$ & $+/-$ & 0.07 & 0.25 & 0.00 & 1.00 \\
\hline DUM_2015 & $\begin{array}{l}\text { Dummy variable indicating the year } 2015 \text { when as } \\
\text { a result of Swiss franc loan conversion banking } \\
\text { sector recorded significant losses and as a result } \\
\text { leverage increased (bin.) }\end{array}$ & $+/-$ & 0.03 & 0.17 & 0.00 & 1.00 \\
\hline GAP & $\begin{array}{l}\text { Log of output gap calculated as: log ((absolute } \\
\text { value of lowest real GDP growth rate in whole } \\
\text { sample) + real GDP growth in a year)) (In rel.) }\end{array}$ & $+/-$ & 0.10 & 0.03 & 0.00 & 0.14 \\
\hline \multicolumn{7}{|c|}{ Governance related variables } \\
\hline DUM_OWN & $\begin{array}{l}\text { Dummy variable indicating that bank is managed } \\
\text { by owners (bin.) }\end{array}$ & + & 0.32 & 0.47 & 0.00 & 1.00 \\
\hline DUM_DIS & $\begin{array}{l}\text { Dummy variable indicating that the ownership of } \\
\text { bank equity is disperse (bin.) }\end{array}$ & - & 0.26 & 0.44 & 0.00 & 1.00 \\
\hline DUM_FOR & $\begin{array}{l}\text { Dummy variable indicating that bank is foreign } \\
\text { owned (bin.) }\end{array}$ & $+/-$ & 0.31 & 0.46 & 0.00 & 1.00 \\
\hline DUM_GOV & $\begin{array}{l}\text { Dummy indicating that bank is government owned } \\
\text { (bin.) }\end{array}$ & $+/-$ & 0.11 & 0.31 & 0.00 & 1.00 \\
\hline
\end{tabular}

Source: Authors' depiction.

Dummy variables for 1998 and 2015 are included because banking sector recorded significant losses in those rather specific years: in 1998 due to the banking crisis and in 2015 due to the Swiss franc conversion. Those specific one-off events might have triggered managers to increase efforts and perhaps deviate from usual effort. We do not include dummy variable for the year 2008, as beginning of the global financial crisis was not reflected in the profitability of banks in Croatia (as 
shown in Figure Al in Appendix). Finally, governance related variables represent a vector of dummy variables explaining bank characteristics that could possibly influence agency costs. We expect that banks that are being run by owners have higher profit efficiency, as by definition in theory, they have no agency costs. On the other hand, in case that the ownership of bank is dispersed, and all shareholders have $25 \%$ or less equity, we expect agency costs to be higher and therefore PREFF lower. We also expect that owners residency could be a factor in bank PREFF and we therefore include a dummy variable for foreign and government owned banks, as we expect that foreign owners possess the business know-how which enables foreign owned banks to be relatively more profitable than their domestic competitors.

\section{The model}

We test agency costs hypothesis by regressing bank specific profit efficiency on the leverage indicator and other control variables (Equation 15):

$$
E F F_{i t}=\beta \cdot x_{i t}+\varepsilon_{i t} \text {, }
$$

where $E F F_{i t}$ is a measure of bank i's profit, cost or revenue efficiency in the year $t, \beta$ is a vector of coefficients, $x_{i t}$ is a vector of control variables observed in year $t$ for the bank $i$ and $\varepsilon_{i t}$ is a normally distributed error term $\left(\varepsilon_{i t} \sim N\left(0, \sigma^{2}\right)\right.$ ) (Table A2 in Appendix shows the correlation matrix between control variables).

Having in mind that our dependent variable is censored and can reach a maximum value of 1 and that there is a noticeable number of observations that, due to the construction of DEA model, take that border value, we employ a censored regression linear model proposed by Tobin (1958) which is more known as Tobit model. Tobit model is designed to estimate linear relationship between variables when there is censoring in the dependent variable. In our case, data can take values of 1 and less, therefore, our data is left censored or censored from bellow (Equation 16). It supposes that there is a latent variable $\bar{y}_{i t}$ that linearly depends on $x_{i t}$ :

$$
\bar{y}_{i t}=x_{i t} \cdot \beta+\varepsilon_{i t},
$$

and which can define the dependant variable of the model as in Equation 17:

$$
\text { PREFF } i t=\left\{\begin{array}{c}
\bar{y}_{i t} \text { if } \bar{y}_{i t}<1 \\
1 \text { if } \bar{y}_{i t} \geq 1
\end{array}\right. \text {. }
$$

Parameters of the model $(\beta)$ are estimated by the maximum likelihood (ML) method which maximises the log-likelihood function. Assuming that the disturbance term $\varepsilon_{t}^{i}$ follows a normal distribution with mean 0 and variance $\sigma^{2}$, the log-likelihood function is defined as in Equation 18:

$$
\left.\ell\left(\beta, \sigma^{2}\right)=\sum_{i: P R E F F}{ }_{i t}=1 \log \Phi\left(\frac{x_{i t} \cdot \beta_{t}-1}{\sigma}\right)+\sum_{i: P R E F F}<1<1 \log \phi\left(\frac{\text { PREFF }_{i t}-x_{i t} \cdot \beta_{t}}{\sigma}\right)-\log \sigma\right],
$$

where $\phi(\cdot)$ and $\Phi(\cdot)$ denote the probability density function and the cumulative distribution function of the standard normal distribution.

\section{Results}

Standard bank performance indicators reveal that Croatian banking sector went through three different periods from 1994 onwards (Figure Al in Appendix). The first period from 1994 to 1999 was characterised by high volatility in bank market structure as the number of banks initially increased and reached 60 in 1997. However, with the increase in the number of banks, the number of problems within the banking sector accumulated, which was masked with high interest rates that provided temporary shelter for banks with lower efficiency and inferior credit risk management. In late nineties banking crises lead to large bank losses bringing ROA 
to around $-2 \%$ and subsequently triggering the process of market cleansing. In the second period, 2000-2008, banking sector enjoyed a period of moderation as profits were reasonably high (ROA $1.4 \%$ on average) and losses related to credit risk were relatively low as the rigorous process of reclassification of loan portfolio from the crisis of 1998 created a solid basis for following growth. The number of banks continued to decrease, primarily as a result of market consolidation. Also, net interest margin stabilized in this period at levels around $2.5 \%$ to $3.0 \%$, comparable with today's level. Finally, in years 2009-2015 the financial crisis left its mark on the banking sector with credit risk costs increasing from 2008 onwards. Unlike the crisis in late 90's, credit losses were initially lower but the process lasted longer which was caused by prolonged period of slow economic activity. In 2015, credit losses increased further with Swiss franc conversion costs bringing ROA to the levels even lower than the ones recorded in the period of bank crisis at around $-1.5 \%$.

Our measure of banks' profit efficiency is not that volatile as ROA as the majority of profitability dynamics comes from credit risk and other activities not under direct influence of management decisions (Figure 1). On average, from 1994 to 2015 aggregate bank profit efficiency did increase from around $60 \%$ to around $80 \%$. This means that banking sector managed to generate just $60 \%$ of profits that most efficient bank on market could achieve controlling for the size and prices. By 2015, this ratio increased to $80 \%$ reflecting improvements in efficiency. It should be noted that mean profit efficiency also increased by around 20 percentage points, starting at around $30 \%$ in 1994 and finishing around 50\% in 2015, mean profit efficiency amounted to $40 \%$ most of the time.

In the same time, the leverage of banks was more stable and with far less differences between banks. The volatility of leverage indicator in late nineties is a reflection of instability caused by banking crisis as leverage increased when banks faced losses and saw their capital decrease (histogram of bank leverage is given in Figure A2 in Appendix). After 1998, bank leverage recorded a period of growth that was interrupted by two years of stronger recapitalisations (2006 and 2008). After 2008, there were no recapitalisations, and with domestic deposits continuing to grow, leverage was increasing. In 2015, due to high costs of Swiss franc loans conversion, leverage increased as recognised losses decreased bank capital.

Our results show that the higher leverage ratio is generally associated with lower profit efficiency which is in contrast with the Agency theory (Table 3). Our results are consistent and robust in all model specifications. In our full specifications model, 1 percentage point increase in leverage would in fact lead to decrease of bank profit efficiency by 1.1 percentage points. Bank size is a positive determinant of profit efficiency as size allows banks more manoeuvring space. Regarding the structural and macro variables, higher market concentration, measured with $\mathrm{HHI}$, is negatively connected with profit efficiency which is in line with the quiet-life hypothesis. Regarding governance related variables, profit efficiency seems to be positively connected with owners running the bank, which is in line with the agency theory. In fact, if owners take full control of the company, then agency costs should by definition amount 0 . Also, disperse ownership is as expected negatively connected with profit efficiency. Finally, foreign ownership seems to be positively contributing to bank profit efficiency. 


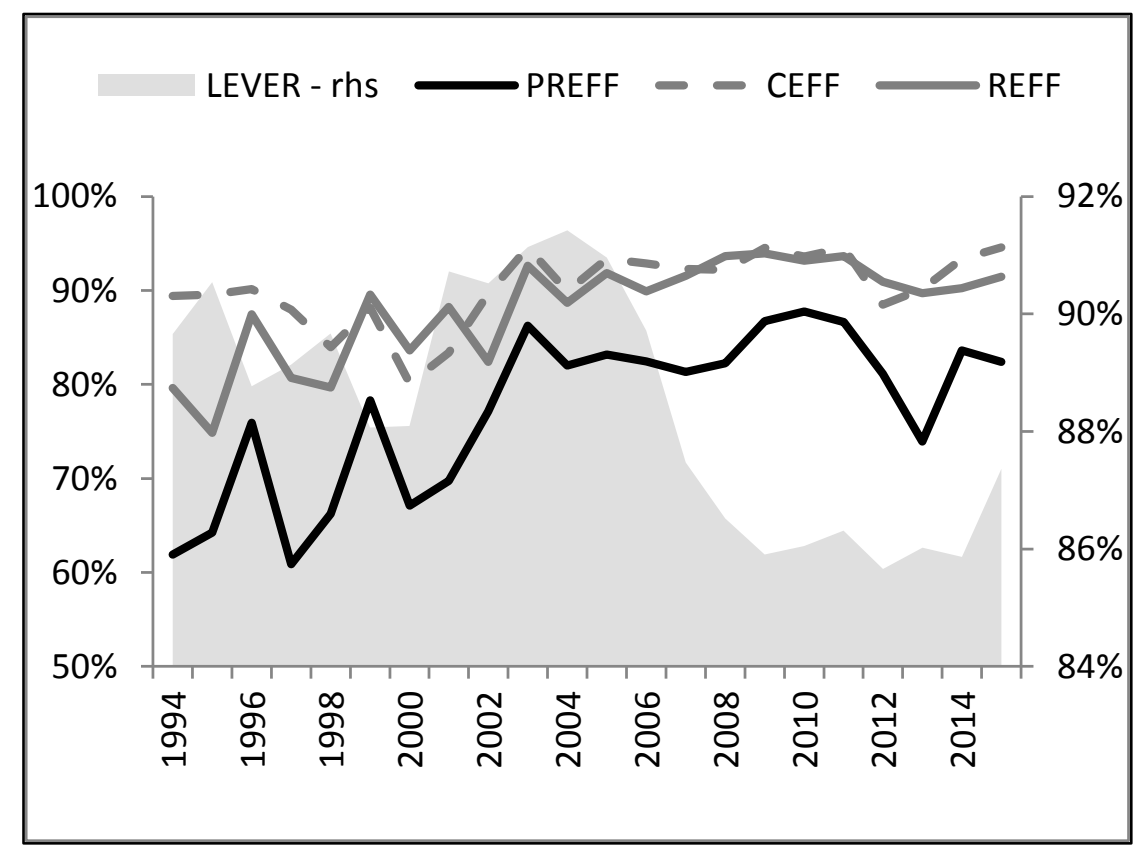

Figure 1 Efficiency measures and leverages (weighted mean)

Legend: LEVER - leverage, REFF - Revenue efficiency, PREFF - Profit efficiency, CEFF - Cost efficiency

Source: Authors' calculation based on HNB data.

Having a comprehensive measure of bank efficiency (profit efficiency) allows us to use its components for testing the agency cost of debt (Table 4). The rationale for this approach is the fact that bank revenue efficiency is less under the control of bank managers than bank cost efficiency. Although our measures are designed not to include credit risk materialisation in revenue efficiency considerations, credit risk is still present as lower credit quality decreases interest income. It is due to this reason why the majority of bank efficiency research actually refers to the bank cost efficiency calculation.

Table 3 Econometric model results for profit efficiency

\begin{tabular}{|l|c|c|c|c|}
\hline & Bank specific & $\begin{array}{c}\text { Structural and } \\
\text { macro }\end{array}$ & $\begin{array}{c}\text { Corporate } \\
\text { Governance }\end{array}$ & $\begin{array}{c}\text { Full specification } \\
\text { model }\end{array}$ \\
\hline LEVER & $-0.935^{* *}$ & & & $-1.070^{* * *}$ \\
\hline LEVER_SQ & -0.423 & & & 0.171 \\
\hline CR_RISK & $0.679^{*}$ & & & 0.475 \\
\hline LN_SIZE & $0.153^{* * *}$ & & & $0.136^{* * *}$ \\
\hline HHI & & -1.575 & & -1.444 \\
\hline DUM_1998 & & -0.022 & & 0.061 \\
\hline DUM_2015 & & -0.11 & & 0.065 \\
\hline GAP & & & $0.070^{*}$ & $0.908^{* *}$ \\
\hline DUM_OWN & & & $-0.164^{* * *}$ & $-0.095^{* * *}$ \\
\hline DUM_DIS & & & $0.312^{* * *}$ & $0.138^{* * *}$ \\
\hline DUM_FOR & & $0.705^{* * *}$ & $0.326^{* * *}$ & 0.05 \\
\hline DUM_GOV & & & & $-0.631^{* * *}$ \\
\hline CONSTANT & $-0.821^{* * *}$ & 825 & 816 & 816 \\
\hline Statistics & & 0.01 & 0.20 & 0.37 \\
\hline $\begin{array}{l}\text { N. Of obs. } \\
\text { Multiple } \\
\text { correlation } \\
\text { coefficient }\end{array}$ & 825 & & & \\
\hline
\end{tabular}

Legend: * $p<0.05 ;{ }^{* *} p<0.01 ;{ }^{* * *} p<0.001$

Source: Authors' calculation. 
As expected, judging by the multiple correlation coefficients, model explaining revenue efficiency has lower goodness of fit compared with model explaining cost efficiency. Overall sample the leverage has a significant negative sign, however according to the theory, this relationship is not necessarily linear and therefore, we also use squared value of leverage. The square value of leverage has a significant positive sign indicating that the relationship between leverage and cost efficiency indeed is not linear and that the relationship changes at very high leverage. Therefore, after certain point, increasing the leverage is connected with the increase of cost efficiency.

Table 4 Econometric model results for cost and revenue efficiency

\begin{tabular}{|l|c|c|c|c|c|c|c|c|}
\hline & \multicolumn{3}{|c|}{ Cost efficiency } & \multicolumn{3}{c|}{ Revenue efficiency } \\
\cline { 2 - 8 } & $\begin{array}{c}\text { Bank } \\
\text { specific }\end{array}$ & $\begin{array}{c}\text { Structural } \\
\text { and macro }\end{array}$ & Governance & Full model & $\begin{array}{c}\text { Bank } \\
\text { specific }\end{array}$ & $\begin{array}{c}\text { Structural } \\
\text { and macro }\end{array}$ & Governance & Full model \\
\hline LEVER & $-0.720^{* * *}$ & & & $-0.767^{* * *}$ & $-0.679^{* *}$ & & & $-0.627^{* *}$ \\
\hline LEVER_SQ & 0.347 & & & $0.569^{*}$ & -0.149 & & & 0.046 \\
\hline CR_RISK & 0.176 & & & 0.234 & 0.28 & & & 0.253 \\
\hline LN_SIZE & $0.073^{* * *}$ & & & $0.061^{* * *}$ & $0.071^{* * *}$ & & & $0.053^{* * *}$ \\
\hline HHI & & -0.876 & & $-0.870^{*}$ & & -0.028 & & 0.041 \\
\hline DUM_1998 & & $-0.094^{* *}$ & & $-0.057^{*}$ & & -0.012 & & 0.017 \\
\hline DUM_2015 & & $0.113^{* *}$ & & $0.089^{* *}$ & & 0.093 & & 0.079 \\
\hline GAP & $-1.044^{* * *}$ & & $-0.382^{*}$ & & -0.172 & & 0.352 \\
\hline DUM_OWN & & & & $0.045^{* *}$ & & & 0.022 & 0.026 \\
\hline DUM_DIS & & & & $-0.041^{* *}$ & & & $-0.120^{* * *}$ & $-0.083^{* * *}$ \\
\hline DUM_FOR & & & & $0.046^{* *}$ & & & $0.138^{* * *}$ & $0.075^{* * *}$ \\
\hline DUM_GOV & & & & 0.015 & & & $0.061^{* *}$ & 0.027 \\
\hline CONSTANT & $0.160^{*}$ & $0.931^{* * *}$ & & $0.419^{* * *}$ & $0.367^{* * *}$ & $0.772^{* * *}$ & $0.734^{* * *}$ & $0.458^{* * *}$ \\
\hline Statistics & & & & & & & & 799 \\
\hline N. Of Obs. & 813 & 813 & 804 & 804 & 808 & 808 & 799 & 799 \\
\hline $\begin{array}{l}\text { MUltiple } \\
\text { correlation } \\
\text { coefficient }\end{array}$ & 0.27 & 0.06 & 0.10 & 0.31 & 0.21 & 0.01 & 0.18 & 0.27 \\
\hline
\end{tabular}

Legend: * $p<0.05 ;{ }^{* *} p<0.01 ; * * * p<0.001$

Source: Authors' calculation.

The discrepancies between actual and predicted values for all three models are satisfyingly low (six, three and four percentage points on average for profit, cost and revenue efficiency) which is illustrated in Figures 2-4. 


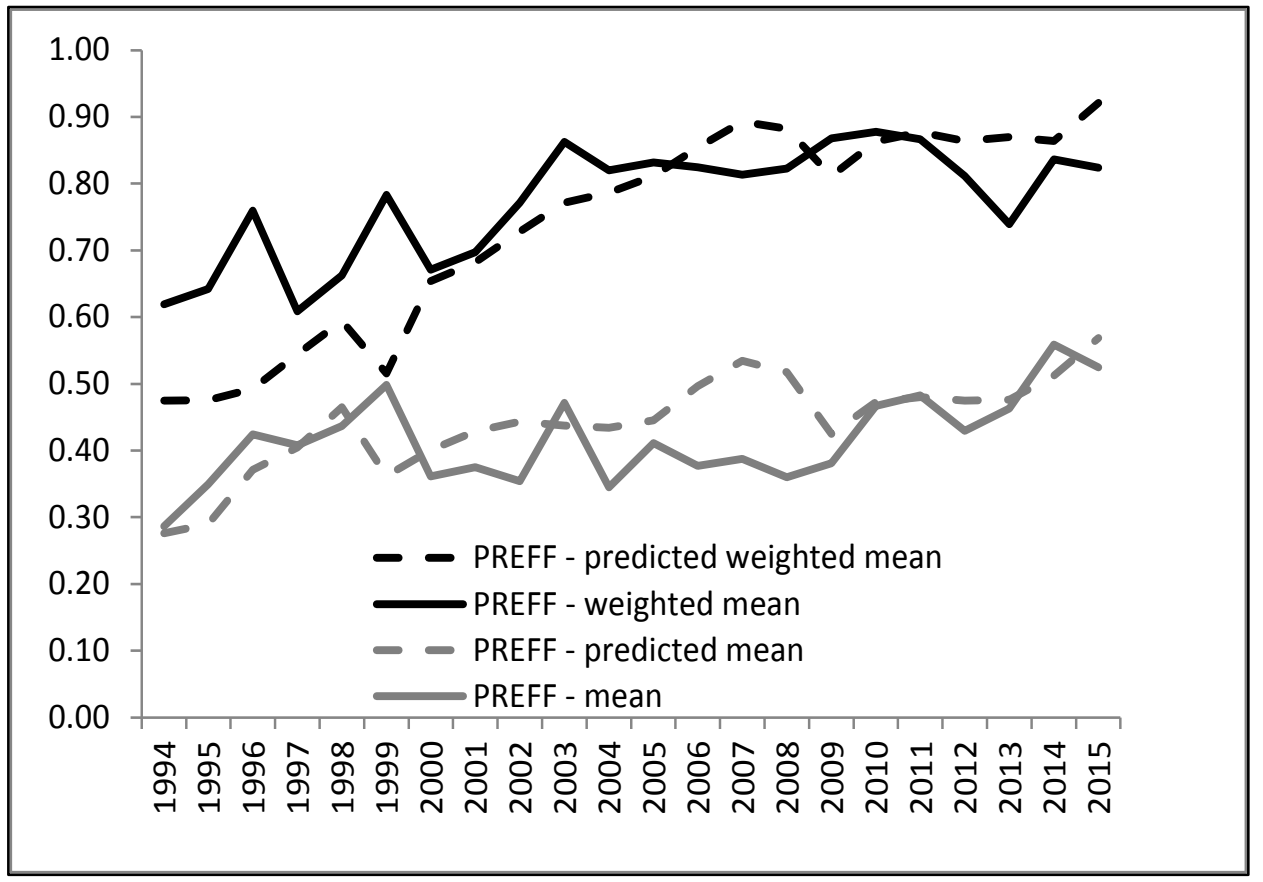

Figure 2 Comparison of actual and predicted values of profit efficiency Legend: PREFF - Profit efficiency

Source: Authors' calculation.

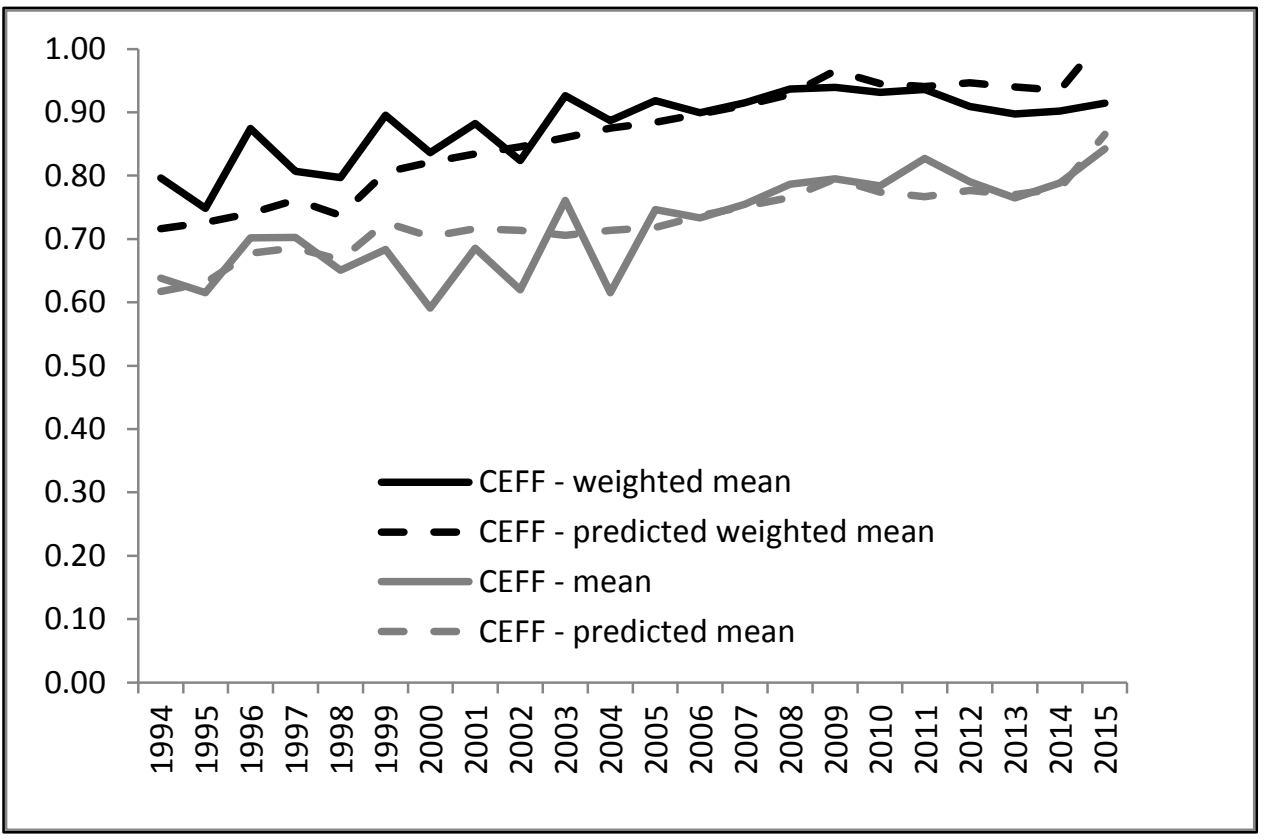

Figure 3 Comparison of actual and predicted values of cost efficiency Legend: CEFF - Cost efficiency

Source: Authors' calculation. 


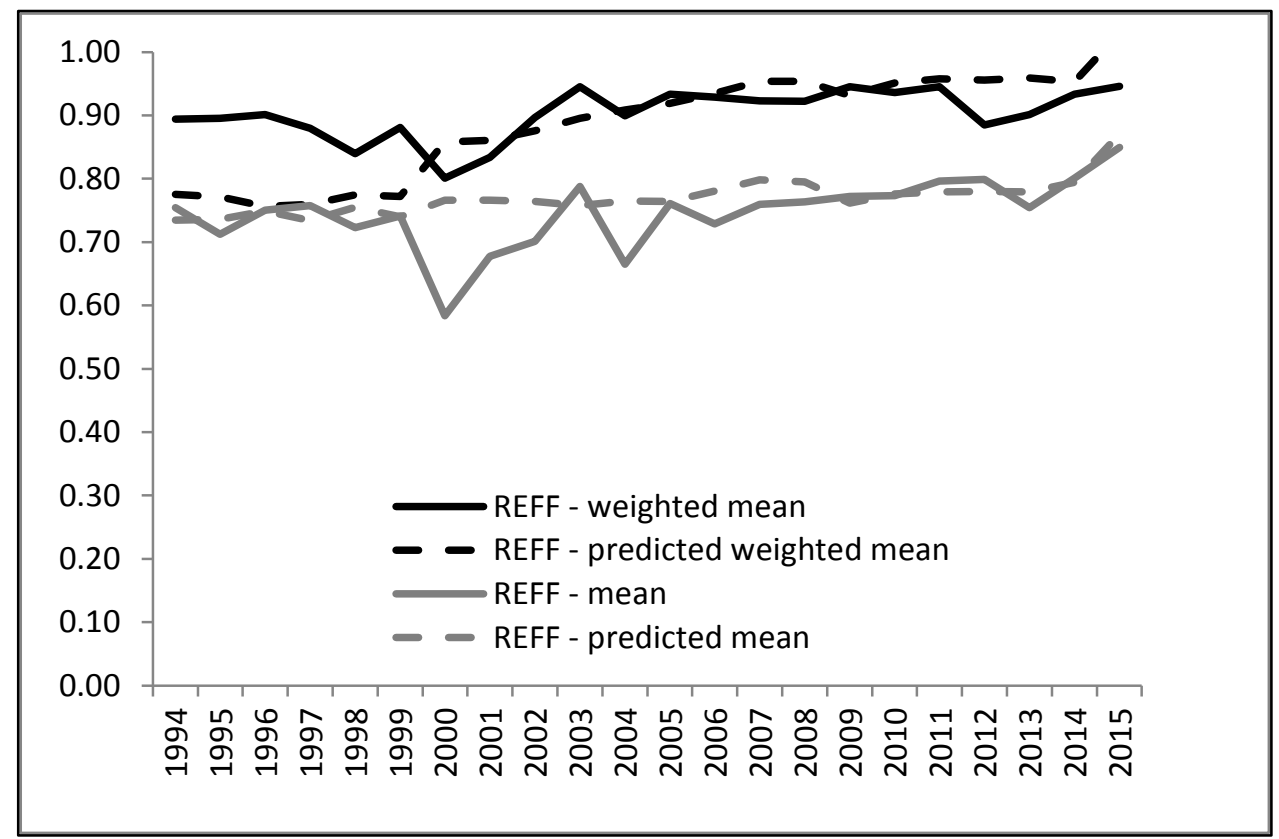

Figure 4: Comparison of actual and predicted values of revenue efficiency Legend: REFF - Revenue efficiency

Source: Authors' calculation.

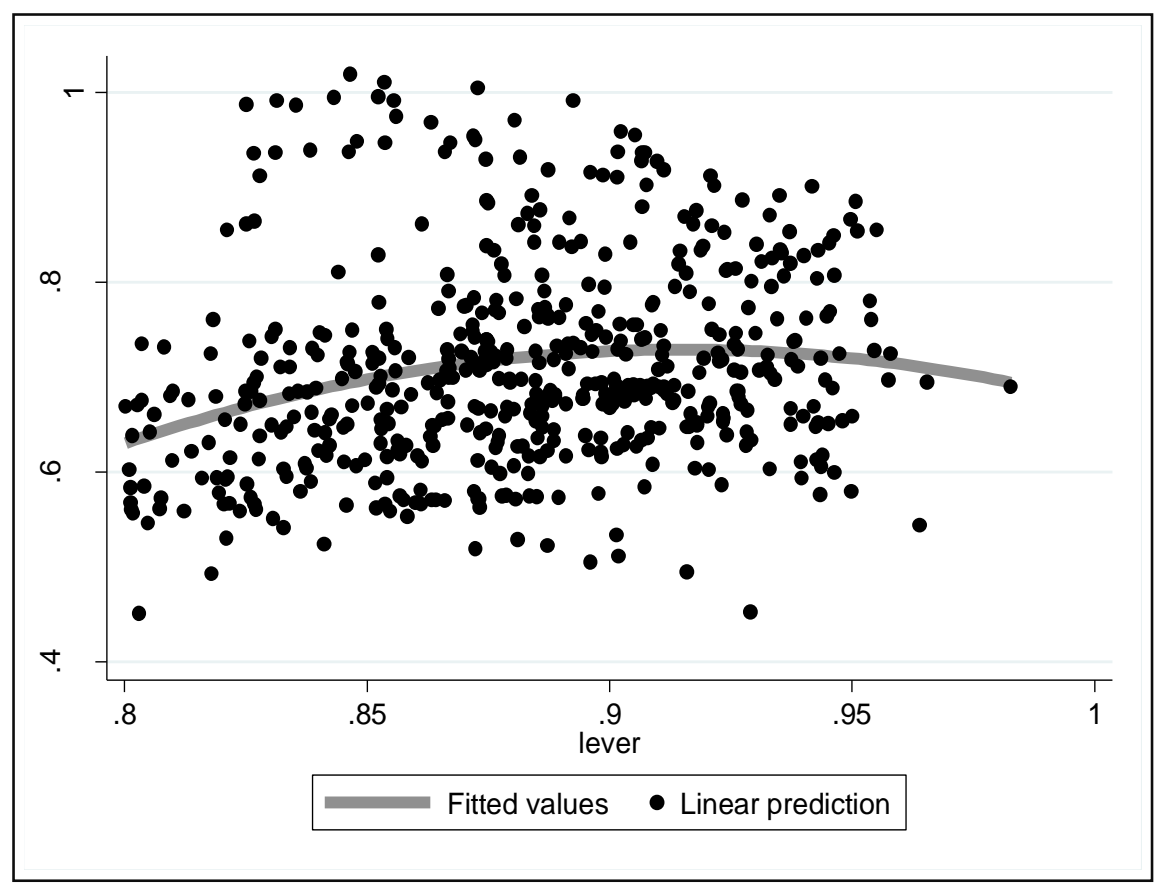

Figure 5 Scatter diagram between cost efficiency and leverage with quadratic fitted Source: Authors' calculation.

line

Finally, using the whole sample for estimation of relationship between leverage and cost efficiency can be misleading for multiple reasons. First, our sample includes observations when banks just entered into the market and for the first year, they were financed almost exclusively through equity. Second, in some cases, when banks were in the process of leaving the market their leverage ratio was reduced to unusually high levels as they were gradually reducing their liabilities. Therefore, it makes sense to observe the relationship between leverage and cost efficiency on 
the leverage levels more typical for banks in Croatia (over $80 \%$ ), which results in reduction of observations by 100 . By increasing leverage from $80 \%$ to $90 \%$, the cost efficiency is increasing leaving some room for agency theory to be valid on that part of the sample. However, on leverage levels higher than $90 \%$, the relationship changes and increasing the leverage results with decreased cost efficiency (Figure 5). Although our sample includes 21 years, the number of observations is still rather low, which does not allow for strong and definite statements about the validity of agency theory in the long run.

\section{Conclusions}

Although we acknowledge that banking industry is specific; highly leveraged and strictly regulated, its specificity is not the reason why the agency theory should not be valid. In this research we tested whether increasing debt leads to increased efficiency in Croatian banking sector in the period from 1994-2015. In order to operationalize the research a measure of profit efficiency consisting of cost and revenue efficiency was created and used as a proxy measure of manager effort. Initially, we found no evidence of existence of such costs as profit efficiency seems to be negatively correlated with leverage.

By looking into the relationship between leverage and cost efficiency we found some evidence that agency theory may hold on "normal" levels of bank leverage (between $80 \%$ and $90 \%$ ). In this range of leverage, increasing the leverage increases the cost efficiency of a bank. Our research is therefore to a certain extent comparable with the one provided by Berger and Bonaccorsi di Patti (2006), however there are a couple of significant differences between the two researches. Since we had far less observations at disposal, we were more inclined to use a linear programming technique to derive a profit efficiency measure. In addition, some of the governance related variables in our study were constructed in form of dummy variables as we have no time series of equity share of managers for Croatian banks as disposal.

Regarding the specificity of Croatian banking market, it is important to mention that although banks in Croatia are public corporations and generally are traded at the stock exchange, they are usually owned by one dominant shareholder making the free-float as well as liquidity of their shares rather low. This is the reason why a lot of research related to agency theory is restricted for Croatian banking industry as certain variables are impossible to construct in consistent fashion (like Tobin a for franchise value). Having a rather undeveloped local capital market, banks in Croatia are used to "living without it", financing their operations directly either via owners (equity and debt) or in most cases from domestic non-financial sector deposits. Also, it is worth mentioning that often the decisions on bank leverage were made outside of the banks. For instance in 2006 and 2008 when Croatian national bank increased the risk weights for FX placements towards un-hedged borrowers, banks responded by recapitalisation. However, after 2008, there have been no significant recapitalisations on the market and dividend payout ratio has increased which together with reducing of deposits and loans from owners is actually creating disinvestment on the market.

Additional research efforts would surely be welcomed in this area as further consolidation of the market is expected. A more detailed data on bank governance is possible to extract but would require a survey type of analysis going back into the past. Also, it could be beneficial to broaden the scope of the research and include either more financial institutions from Croatia (housing banks, insurers, etc.) or include institutions from other country perhaps making a CEE banks sample or EU sample of 
banks. Also, finding the relationship between bank leverage and efficiency, is not enough for testing the agency theory in banking industry as there are other theories explaining the relationship between those two phenomena as well (efficiency-risk hypothesis and the franchise-value hypothesis). Therefore, additional models should be constructed and accompanied by separate causality tests.

\section{References}

1. Admati, A., Hellwig, M. (2013). Does Debt Discipline Bankers? An Academic Myth about Bank Indebtness. Available at https://www.gsb.stanford.edu/faculty-research/workingpapers/does-debt-discipline-bankers-academic-myth-about-bank-indebtedness March 2017].

2. Berger, A., Bonaccorsi di Patti, E. (2006). Capital structure and firm performance: A new approach to testing agency theory and an application to the banking industry. Journal of Banking \& Finance, Vol. 30, No. 4, pp. 1065-1102.

3. Bogetoft, P., Otto, L. (2011). Benchmarking with DEA, SFA, and R. Springer.

4. Dobbin, F., Jung, J. (2010). The misapplication of Mr. Michael Jensen: how agency theory brought down the economy and why it might again. In Markets on Trial: The Economic Sociology of the U.S. Financial Crisis: Part B (Research in the Sociology of Organizations, Volume 30), Lounsbury, M., Hirsch, P. M. (Eds.) Emerald Group Publishing Limited, pp. 29-64.

5. Grossman, S., Hart, O. (1982). Corporate financial structure and managerial incentives. The Economics of Information and Uncertainty, University of Chicago Press.

6. Jensen, M., Meckling, W. (1976). Theory of the Firm: Managerial Behavior, Agency Costs and Ownership Structure, Journal of Financial Economics, Vol. 3, No. 4, pp. 305-360.

7. Modigliani, F., Miller, M. (1958). The Cost of Capital, Corporation Finance and the Theory of Investment. American Economic Review, Vol. 48, No. 3, pp. 261-297.

8. Modigliani, F., Miller, M. (1963). Corporate income taxes and the cost of capital: a correction. American Economic Review, Vol. 53, No. 3, pp. 433-443.

9. Myres, S. (1977), Determinants of corporate borrowing, Journal of Financial Economics, Vol.5, No. 2 p. 147-175.

10.Skopljak, V., Luo R. H. (2012). Capital structure and firm performance in the financial sector: evidence from Australia, Asian Journal of Finance \& Accounting, Vol. 4, No. 1, pp. 278-298.

11.Tobin, J. (1958). Estimation of relationships for limited dependent variables, Econometrica, Vol. 26, No. 1, pp. 24-36.

\section{About the authors}

Mario Bambulović, MsC, in 2011 received the Bachelor's degree and in 2014 the Master of Mathematics degree at the Faculty of Science, department of Mathematics at the University of Zagreb. The author started working at the Financial stability department of Croatian National Bank in the 2014, where he is currently employed. His fields of interest are banking, financial stability, efficiency and financial markets. The author can be contacted at mario.bambulovic@hnb.hr.

Ivan Huljak, PhD, in 2004 received the Bachelor's degree in Finance and in 2010 the Master of Science degree in Corporate Finance at the Faculty of Economics and Business, University of Zagreb. In 2014, he received his PhD in the area of banking and industrial organisation with thesis: "The net effect of bank market power in CEE countries" at Faculty of Economics, University of Split. During his work in Croatian National Bank, he attended various seminars and workshops and presented his work on international conferences on the topics of financial stability. From April 2016 to May 2017 the author worked as Financial Stability Expert at European Central Bank. His field of interest is banking, financial stability and industrial organisation. The author can be contacted at ivhuljak@gmail.com. 
Antonija Kožul, PhD, in 2005 received the Bachelor's degree in Finance and in 2008 the Master of Science degree in Corporate Finance at the Faculty of Economics and Business, University of Zagreb. In 2012, she received his PhD in the area of corporate finance with thesis: "Factors influencing dividend policy" at Faculty of Economics, University of Zagreb. In 2015 she became an Associate Professor of finance. During her work at University of Zagreb, she attended various seminars and workshops and presented his work on international conferences on the topics of dividend policy, risk management and portfolio management. The author currently works as an Associate at McKinsey \& Company. Her field of interest is corporate finance and investment analysis. The author can be contacted at antonijakozul@gmail.com.

\section{Appendix}

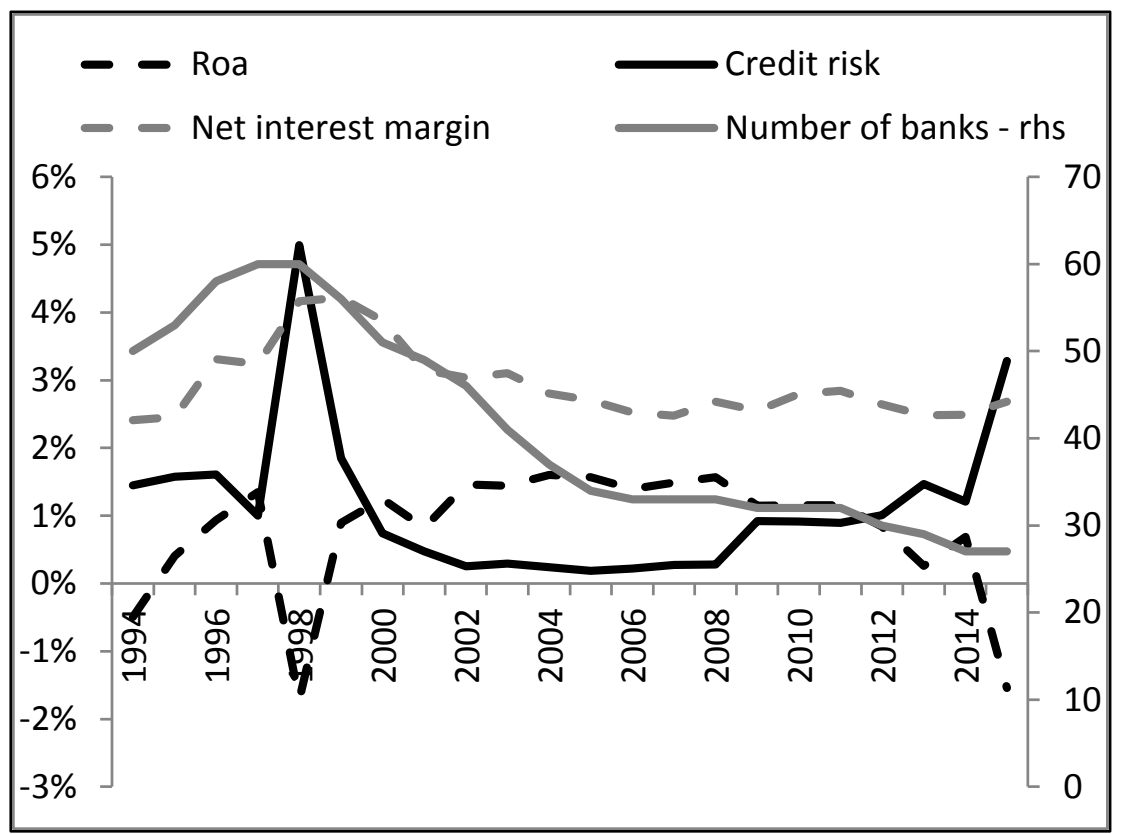

Figure A 1: Selected indicators of bank performance

Source: Authors`creation. 


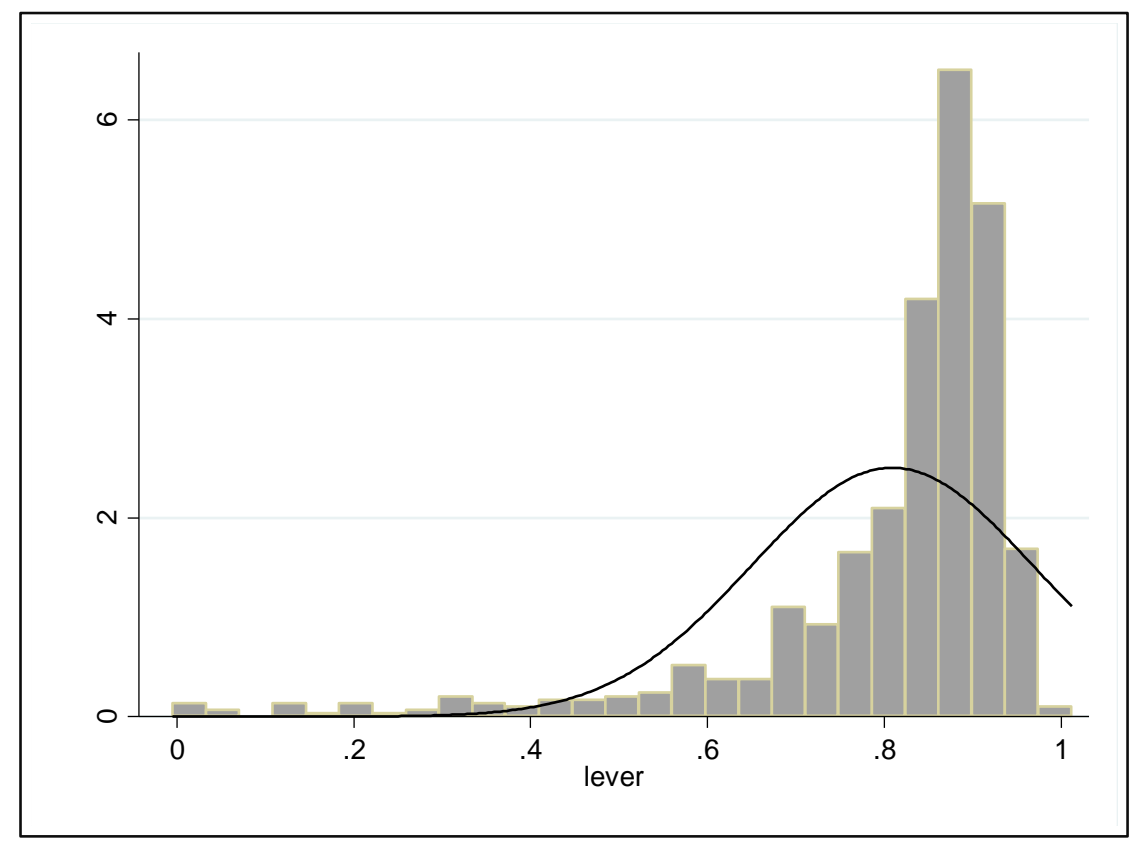

Figure A2: Bank leverage histogram

Source: Authors`creation.

Table Al: Correlation matrix between control variables

\begin{tabular}{|c|c|c|c|c|c|c|}
\hline & LEVER & LEVER_SQ & CR_RISK & LN_SIZE & $\mathrm{HHI}$ & DUM_1998 \\
\hline LEVER & 1.00 & & & & & \\
\hline LEVER_SQ & 0.98 & 1.00 & & & & \\
\hline CR_RISK & -0.11 & -0.11 & 1.00 & & & \\
\hline LN_SIZE & 0.62 & 0.65 & -0.12 & 1.00 & & \\
\hline $\mathrm{HHI}$ & -0.01 & 0.01 & -0.09 & 0.03 & 1.00 & \\
\hline DUM_1998 & -0.05 & -0.06 & 0.30 & -0.09 & -0.50 & 1.00 \\
\hline DUM_2015 & 0.09 & 0.10 & 0.02 & 0.13 & 0.16 & -0.05 \\
\hline GAP & -0.19 & -0.19 & 0.01 & -0.29 & -0.04 & -0.06 \\
\hline DUM_OWN & -0.28 & -0.32 & 0.07 & -0.41 & -0.02 & 0.01 \\
\hline DUM_DIS & 0.19 & 0.19 & 0.04 & -0.08 & 0.01 & 0.06 \\
\hline DUM_FOR & 0.07 & 0.09 & -0.06 & 0.43 & 0.03 & -0.09 \\
\hline \multirow[t]{2}{*}{ DUM_GOV } & 0.10 & 0.12 & 0.01 & 0.12 & 0.03 & 0.01 \\
\hline & DUM_2015 & GAP & DUM_OWN & DUM_DIS & DUM_FOR & DUM_GOV \\
\hline \multirow{2}{*}{\multicolumn{7}{|c|}{$\begin{array}{c}\text { LEVER } \\
\text { LEVER_SQ }\end{array}$}} \\
\hline & & & & & & \\
\hline CR_RISK & & & & & & \\
\hline & & & & & & \\
\hline DUM_1998 & & & & & & \\
\hline DUM_2015 & 1.00 & & & & & \\
\hline GAP & -0.15 & 1.00 & & & & \\
\hline DUM_OWN & -0.03 & 0.03 & 1.00 & & & \\
\hline DUM_DIS & -0.02 & 0.11 & -0.15 & 1.00 & & \\
\hline DUM_FOR & 0.09 & -0.22 & -0.34 & -0.21 & 1.00 & \\
\hline DUM_GOV & -0.02 & 0.10 & -0.17 & 0.00 & -0.24 & 1.00 \\
\hline
\end{tabular}

Source: Authors`calculation. 